\title{
ACCESS TO INFORMATION, SOCIO-CULTURAL FACTOR, AND THEIR RELATIONSHIP WITH READINESS TO PROVIDE EXCLUSIVE BREASTFEEDING AMONG PREGNANT WOMEN
}

\author{
Sri Mulyani1 ${ }^{1}$, AA Subiyanto2), Sapja Anantanyu3), Supriyadi Heri Respati4) \\ 1)Diploma Program in Midwifery, Faculty of Medicine, \\ Sebelas Maret University \\ 2)Masters Program in Family Medicine, Sebelas Maret University \\ 3)Doctoral Program in Development Promotion, Sebelas Maret University \\ 4)Department of Obstetry and Gynecology, \\ Dr. Moewardi Hospital, Surakarta
}

\begin{abstract}
BACKGROUND: Review of evidence has shown that, on a population basis, exclusive breastfeeding for 6 months is the optimal way of feeding infants. Breast milk promotes sensory and cognitive development, and protects the infant against infectious and chronic diseases. Exclusive breastfeeding reduces infant mortality due to common childhood illnesses such as diarrhea or pneumonia, and helps for a quicker recovery during illness. This study aimed to examine the relationship between access to information, socio-cultural factor, and readiness to provide exclusive breastfeeding among pregnant women.

SUBJECT AND METHODS: This was a cross sectional study conducted in Surakarta, Central Java. A sample of 150 pregnant mothers was selected at random from 3 community health centers in Surakarta. The dependent variable was readiness to provide exclusive breastfeeding. The independent variables were access to information and socio-cultural factor. The socio-cultural factor consisted of 3 indicators: (1) Value and belief on colostrum, (2) Value and belief food intake, and (3) Tradition and belief about breastfeeding. A questionnaire was developed to measure these variables. A multiple linear regression model was used to estimate the relationship between variables.

RESULTS: Access to information $(b=0.30 ; p=0.021)$ and positive sociocultural factor $(b=0.20 ; p=0.044)$ increased the readiness of pregnant mothers to provide exclusive breastfeeding, and both relationships were statistically significant.

CONCLUSION: Access to information and positive socio-cultural factor increase the readiness of pregnant mothers to provide exclusive breastfeeding. Health promotion initiative is recommended to improve information access and to enhance positive socio-cultural values and beliefs in order to increase readiness among pregnant mothers to provide exclusive breastfeeding.
\end{abstract}

Keywords: exclusive breastfeeding, access to information, socio-cultural factor 